Research article

\title{
Alternaria polypodiicola, a new foliicolous fungus discovered on Microsorum punctatum from Uttar Pradesh, India
}

\author{
Shambhu Kumar ${ }^{1}$ and Raghvendra Singh ${ }^{2}$ \\ ${ }^{1}$ Department of Forest Pathology, Kerala Forest Research Institute, Thrissur, Kerala, India \\ ${ }^{2}$ Centre of Advanced Study in Botany, Institute of Sciences, Banaras Hindu University, Varanasi. \\ Uttar Pradesh, India
}

*Corresponding Author: skumartaxon@gmail.com

[Accepted: 31 October 2016]

\begin{abstract}
Alternaria polypodiicola sp. nov., is described, illustrated and discussed, causing foliar disease on a pteridophytic plant Microsorum punctatum (Polypodiaceae) from Uttar Pradesh, India. The present species was compared with closely similar species based on morphological characters. This species is characterized by having well developed stromata, unbranched and shorter conidiophores with shorter smooth conidia. A key is provided to all species of Alternaria reported on Polypodiaceae. The description and nomenclatural novelty details were deposited in Mycobank.
\end{abstract}

Keywords: Taxonomy - Foliicolous - Hyphomycetes - Microsorum - Alternaria - New species.

[Cite as: Kumar S \& Singh R (2016) Alternaria polypodiicola, a new foliicolous fungus discovered on Microsorum punctatum from Uttar Pradesh, India. Tropical Plant Research 3(3): 569-572]

\section{INTRODUCTION}

Microsorum punctatum (L.) Copel. is a small evergreen ornamental pteridophytic plant belongs to family Polypodiaceae of Plant kingdom. It is a common fern species in Africa and Asia and occurs naturally in various forest types of tropics and subtropics from sea level up to $2800 \mathrm{~m}$ elevation (Nooteboom 1997, Bosman 1991). The plant shows good medicinal properties. The leaf and juice are used as purgative, diuretic and for healing wounds (May 1978, Sharma \& Pegu 2011).

During the regular observation of plants of the BSIP garden, Lucknow, the living leaves of Microsorum punctatum exhibiting foliar blights was encountered. However, it differs morphologically from previously described Alternaria species and therefore is proposed here as new based on critical microscopic examination and comparison of morphological features with those of the closely similar forms. The details description and illustration of Alternaria polypodiicola is presented here.

\section{MATERIALS AND METHODS}

The diseased plant leaves samples were collected from BSIP Campus, Lucknow during September 2012. The photographs of the infection spots were taken by using a Sony DSC-5730 camera during the time of collection. The collected samples were carried to the laboratory and processed by following the standard techniques (Castañeda-Ruiz 2005, Hawskworth 1974, Savile 1962). The sun dried and pressed leaf specimens were placed in air tight polyethylene bags and then kept in ziplock polythene bag along with collection details. The surface scrapping and free hand cut sections of infected leaf samples were taken through infection spots and mounted in cotton-blue lactophenol mount mixture for microscopic examination. Detailed observations of morphological characters were carried out by means of an Olympus CX31 light microscope (400x) and measurement was done by micrometry. Morphotaxonomic determination was made with the help of current literature pertaining to Alternaria. The holotype specimen has been deposited in Ajrekar Mycological Herbarium (AMH), Agharkar Research Institute, Pune, India future reference. Description and nomenclatural detail were deposited in MycoBank (www.MycoBank.org). The systematics position of the taxa is given in accordance with Cannon \& Kirk (2007), Kirk et al. (2008), Seifert et al. (2011), Farr \& Rossman (2015) and the Index Fungorum (www.indexfungorum.org; accessed 30 April 2015). 


\section{RESULTS}

\section{Taxonomic descriptions}

Alternaria polypodiicola Sham. Kumar \& Raghv. Singh sp. nov. (Fig. 1, 2)

MycoBank MB 817343

Anamorphic fungus, hyphomycetes, Foliicolous, Infection spots amphigenous, initially circular to irregular (5-25 mm diam.), brown, but later on severe infection it spreading on entire surface of the leaves. Colonies

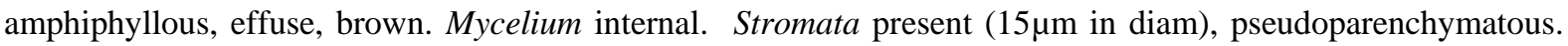
Conidiophores macronematous, fasciculatous (5-7 in a fascicle), straight to curved, simple, cylindrical, unbranched, thick walled, smooth, 1-3 septate, brown, 10-55 × 3-5 $\mu \mathrm{m}$. Conidiogenous cells integrated, terminal, monotretic, scars thickened. Conidia simple, acropleurogenous, solitary to catenate, dry, smooth obclavate to ellipsoidal to ovoid (muriform), rostrum present, 2-4 transversely septate and 2-3 obliquely septate, brown, base obtuse, 20-50 × 10-18 $\mu \mathrm{m}$, hilum thickened (1.5-2.0 $\mu \mathrm{m})$, germinating conidium present.

Material examined: India, Uttar Pradesh, Lucknow, BSIP Campus, on living leaves of Microsorum punctatum (L.) Copel. (Polypodiaceae), $2^{\text {nd }}$ September, 2012, coll. Shambhu Kumar, AMH-9515 (holotype).

Etymology: The specific epithet polypodiicola in reference to host family.

Teleomorph: Undetermined.

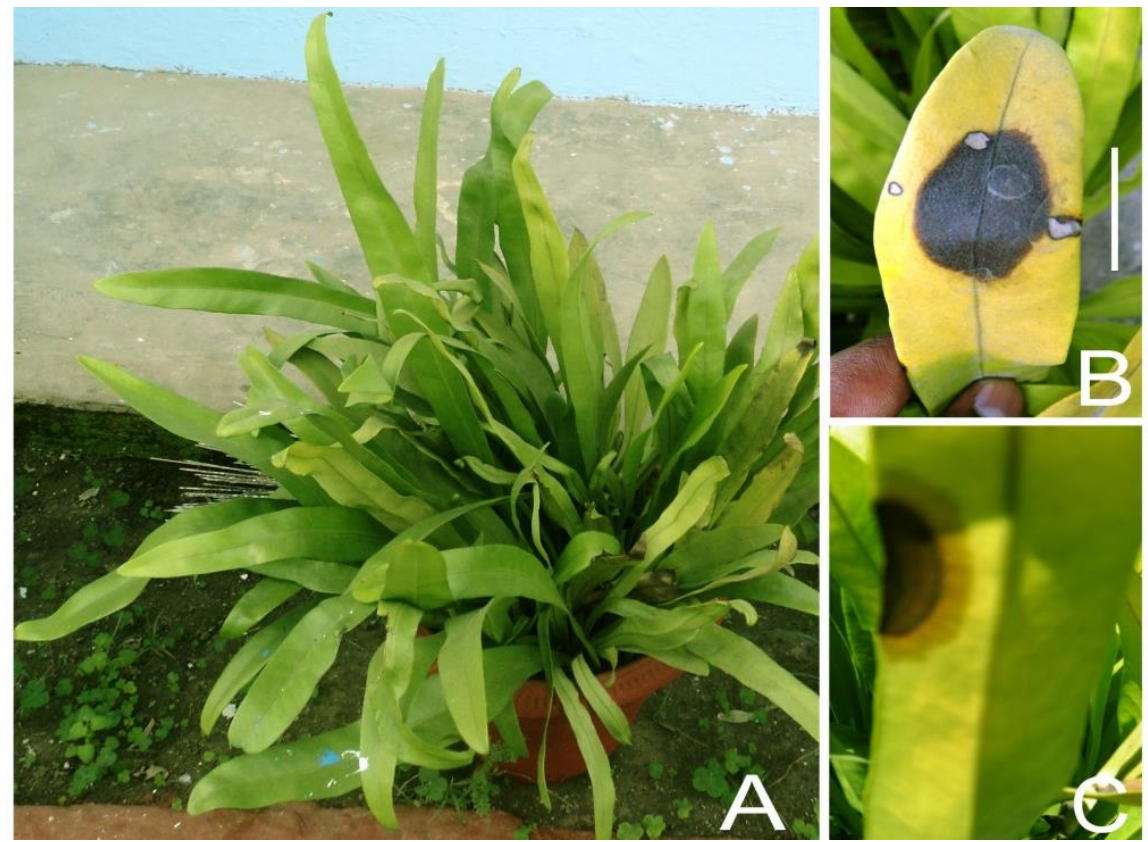

Figure 1. Microsorum punctatum: A, Host Plant; B, Infection spots on upper surface of leaf (Scale bars: B = $20 \mathrm{~mm}$ ); $\mathbf{C}$, Infection spots on lower surface of leaf.

\section{Identification key to Alternaria spp. reported on Polypodiaceae}

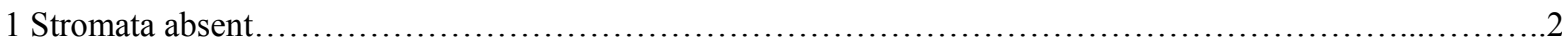

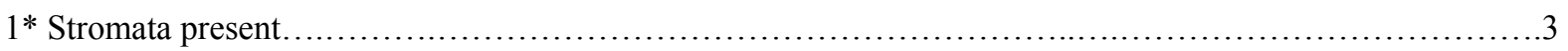

2 Conidiophores up to $50 \times 3-6 \mu \mathrm{m}$, branched......................................................

$2 *$ Conidiophores up to $115 \times 4-6 \mu \mathrm{m}$, simple or unbranched ..........................................

3 Conidiophores $10-55 \mu \mathrm{m} \times 3-5 \mu \mathrm{m}$, unbranched...................................................6

4 Conidia $20-63 \times 9-18 \mu \mathrm{m}, 8$ transversely septate and several obliquely septate, verruculose......... A. alternata

5 Conidia 22-95 $\times 8-19 \mu \mathrm{m}, 4-7$ transversely septate and several obliquely septate,verruculose...A. tenuissima 6 Conidia $20-50 \times 10-18 \mu \mathrm{m}, 2-4$ transversely septate and 2-3 obliquely septate, smooth....... A. polypodiicola

\section{DISCUSSION}

Perusal of literatures indicated that there was no record of Alternaria on this host (Farr \& Rossman, 2015, Bilgrami et al. 1991, Jamaluddin et al. 2004). Alternaria polypodii (invalidly published) on Polypodium sp. and Alternaria sp. on Platycerium bifurcatum and Platycerium sp. from Florida (Farr \& Rossman 2015) have been reported on Polypodiaceae which were very similar to A. alternata. From India, A. alternata was previously reported on Polypodium vulgare L. (Narang et al. 1978) from Allahabad and A. tenuissima (Kunze ex Pers) 
Wilt. on Polypodium multilineatum L. (Kanaujia et al. 1978) from Faizabad respectively on the family Polypodiaceae. Therefore, the present fungus was compared with these two earlier reported species.

The stromata is present in A. polypodiicola while absent in earlier described species. The conidiophores are unbranched and very much shorter $(10-55 \times 3-5 \mu \mathrm{m})$ in A. polypodiicola while branched and longer (up to $50 \times$ 3-6 $\mu \mathrm{m}$ ) in A. alternata and A. tenuissima (simple or unbranched and up to $115 \times 4-6 \mu \mathrm{m}$ ). The Conidia of $A$. polypodiicola are shorter $(20-50 \times 10-18 \mu \mathrm{m})$ than both previously described A. alternata $(20-63 \times 9-18 \mu \mathrm{m})$ and A. tenuissima $(22-95 \times 8-19 \mu \mathrm{m})$. The conidia of novel species are smooth while verruculose in both the earlier described species. Thus, A. polypodiicola is treated as a new species.
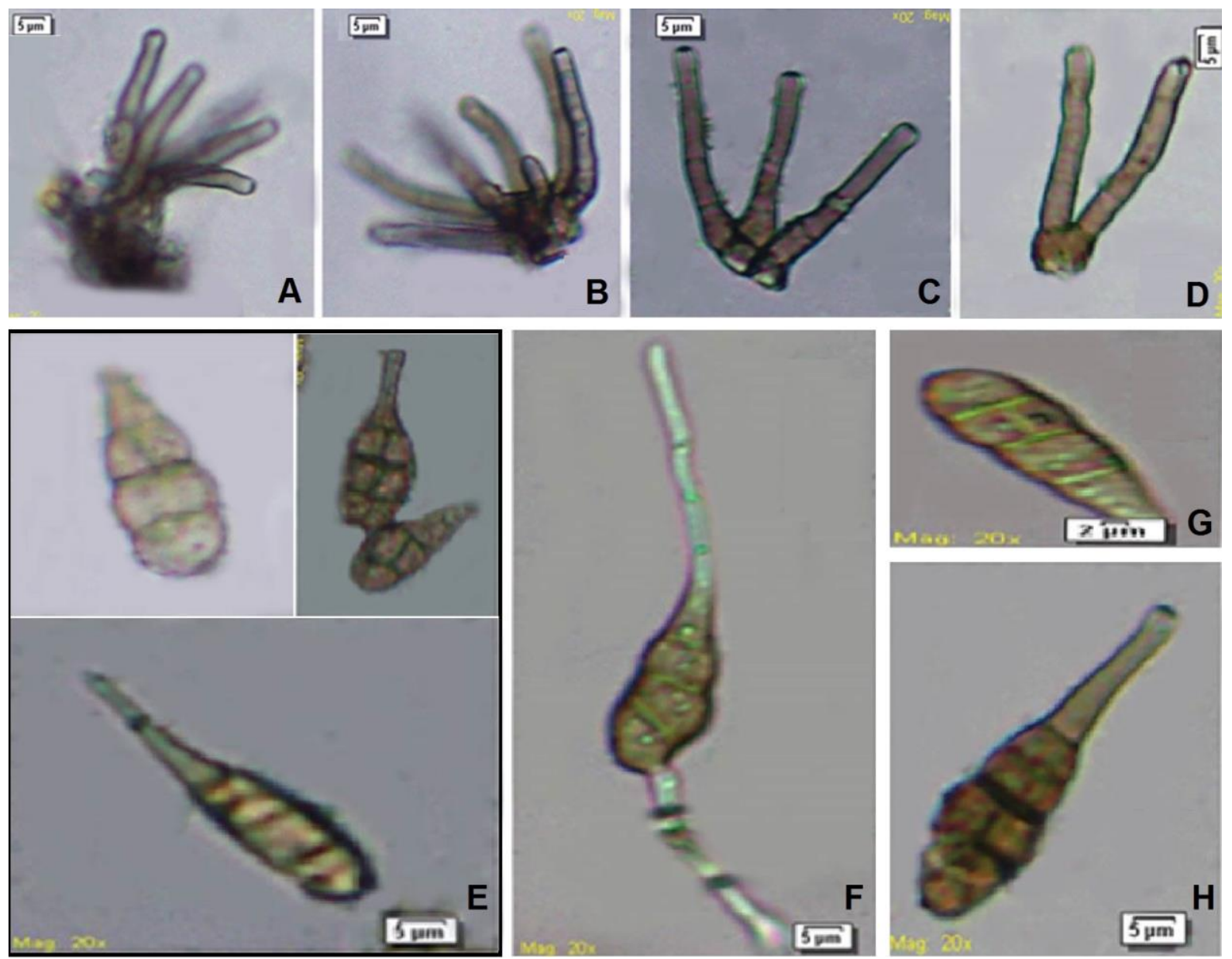

Figure 2. Alternaria polypodiicola (AMH-9515, holotype): A-D, Conidiophores; $\mathbf{E}-\mathbf{H}$, Conidia. (Scale bars A-H $=5 \mu \mathrm{m}$ )

\section{ACKNOWLEDGEMENTS}

Authors' are thankful to the Director Kerala Forest Research Institute, Peechi for encouragement and necessary facilities. Thankfulness is also due to the Curator, Ajrekar Mycological Herbarium (AMH), Agharkar Research Institute, Pune (MS), India for depositing specimen and providing accession number thereof. We are also grateful to Dr. Ajit Pratap Singh, Senior Scientist, CSIR-NBRI, Lucknow, for the host identification. Shambhu Kumar is grateful to Science and Engineering Research Board (SERB), Department of Science and Technology (DST), Government of India, New Delhi for financial support (SB/YS/LS-288/2013).

\section{REFERENCES}

Bilgrami KS, Jamaluddin \& Rizwi MA (1991) Fungi of India: List and references. Today's and Tomorrow's Printers and Publishers, New Delhi. pp. 798.

Bosman MTM (1991) A Monograph of the Fern Genus Microsorum (Polypodiaceae). Rijksherbarium/Hortus Botanicus, Leiden, the Netherlands.

Cannon PF \& Kirk PF (2007) Fungal Families of the World. Wallingford, UK: CAB International. pp. 456.

Castañeda-Ruiz RF (2005) Metodologíaen el estudio de loshongosanamorfos. Anais do V Congresso Latino Americano de Micología. Brasilia, pp. 182-183. 
Farr DF \& Rossman AY (2015) Fungal Databases, Systematic Mycology and Microbiology. ARS, USDA. Available from: http://nt.ars-grin.gov/fungaldatabases/ (accessed: 30 Apr. 2015).

Hawskworth DL (1974) Mycologist's Handbook. CMI, Kew. pp. 231.

Index Fungorum (2015) Index Fungorum. Available from: http://www.indexfungorum.org/ (accessed 30 Apr. 2015).

Jamaluddin, Goswami MG \& Ojha BM (2004) Fungi of India 1989-2001. Scientific Publishers, Jodhpur, Rajasthan, India. pp. 326.

Kanaujia RS \& Raj Kishore (1978) Annoted list of Fungi from Faizabad (U.P.), India. Indian Journal of Mycology and Plant Pathology 8: 188-194.

Kirk PF, Cannon PF, Minter DW \& Stalpers JA (2008) Dictionary of the Fungi, $10^{\text {th }}$ ed. Wallingford, UK: CAB International. pp. 402.

May LW (1978) The economic uses and associated folklore of ferns and fern allies. Botanical Review 44(4): 491-528.

MycoBank (2015) Fungal databases nomenclature and species banks. Available from: http://www.mycobank.org/ (accessed: 30 Apr. 2015).

Narang M \& Chandra S (1978) Some new leaf spot diseases of ferns from India. Acta Biologica Indica 6: 108114.

Nooteboom HP (1997) The microsoroid ferns (Polypodiaceae). Blumea 42: 261-395

Savile DBO (1962) Collection and care of Botanical specimens. Department of Agriculture, Canada, pp. 1113.

Seifert K, Morgan-Jones G, Gams W \& Kendrick B. (2011) The Genera of Hyphomycetes. CBS Biodiversity Series 9: 1-997.

Sharma UK \& Pegu S (2011) Ethnobotany of religious and supernatural beliefs of the Missing tribes of Assam with special reference to the 'Dobur Uie'. Journal of Ethnobiology and Ethnomedicine 7(1): 16. 